\title{
EVALUATION OF SUSTAINABLE DEVELOPMENT FRAMEWORK FOR VOCATIONAL COLLEGES: IMPLEMENTATION AND CHALLENGES
}

\author{
${ }^{1 *}$ Asnul Dahar Minghat, ${ }^{2}$ Siti Nadia Mohd Safie \& ${ }^{3}$ Siti Salina Mustakim \\ ${ }^{1}$ Dr., Faculty of Education, Universiti Teknologi Malaysia, MALAYSIA, \\ Email: asnuldahar@gmail.com \\ ${ }^{2}$ Ms., Faculty of Education, Universiti Teknologi Malaysia, MALAYSIA. Email: nadia@gmail.com \\ ${ }^{3}$ Dr., Institut Aminuddin Baki, National Institute of Educational Leadership and Management, \\ Ministry of Education, MALAYSIA. Email: sitisalina@iab.edu.my \\ ${ }^{*}$ Corresponding author
}

\begin{abstract}
The main purpose of this study was to explore the extensive growth of courses among the Vocational Colleges developed by the Ministry of Education since 2012. In order to determine the sustainability of the development, this study specifically seeks to explore the scope and quality of Vocational Colleges' Curriculum Standard implementation via the integration of sustainability development among educators, and to investigate challenges occurred during the implementation of the college ever since. Findings indicated that the implementation of curriculum in the colleges has made clear the infusion of sustainability from the interviews and surveys conducted among teachers and panel experts in Technical and Vocational Education and Training. It fulfills the vision and mission aspired by the education ministry. In other circumstances, majority of the respondents argued on the inconsistency of its implementation. The misconception of understanding its curriculum as well as its implementation in the schools system has made them doubt with the career path of the students in the future. This study proposed nine elements of sustainable development for vocational colleges' course to be implemented in the curriculum using the Delphi techniques. They are the skills, counselor, committed management, internship among industries, collaboration and partnership, teaching techniques, entrepreneurship, soft skills, and curriculum.
\end{abstract}

Keywords: sustainability, implementation, challenges, Vocational Colleges

\section{INTRODUCTION}

The development of vocational education is outlined as the main strategy of the New Economic Policy, which aims to eradicate poverty and restructure the society (Rahmah, 2003). People have high hope for education which will give future generations opportunities for social mobility and to free them from the shackles of poverty (Hasnah and Noraziah 2007; Nor Aini 2002, Rahmah 2003).

The transformation of technical and vocational education (TVE) in Malaysia began in 2012 by the Ministry of 
Education. It is a business of devising curricula, institutions, teaching and learning, assessment, governance and human resource. Transformation of TVE is focusing on the component business and work ability to make Malaysia as a high-income nation. The education sector, particularly in TVE has transformed in many dimensions. All these are done for the sake of global human capital that has high competition and skills. In developed countries such as Germany, TVE and vocational training are the main choice of students due to its provision of good career prospects (Ivan, 2007). By contrast, in Malaysia, it is still viewed as the last resort due to the perception of limited career prospects. These negative assumptions should be denied because TVE and vocational training in reality provide the basis platform for a good alternative amongst students to realize future potential of an individual (Mohd Fuad, 2010).

Vocational College (VC) is an institution of education and vocational training implementing the Standard Curriculum Vocational College (SCVC) for the purpose of forming a moral human capital, educated and highly skilled worker. VC students learning orientation is a work-based learning and training in the workplace or so-called the on-job training (OJT). VC graduates are expected to be a skilled worker in a particular field of vocational qualifications of (1) Vocational College Certificate, (2) Diploma of Vocational Malaysia, and (3) International Professional Qualification. The objectives of VC established in the context of developing human capital, educated, and highly skilled students. Its planning and implementation are to achieve the following's general objectives of (1) express a high level of employment competent and meet the requirements of industry, (2) foster professional character, (3) produce competent students of entrepreneurs in the field of vocational choice, (4) supply knowledge to continue their studies at a higher levels, and (5) love for lifelong learning.

This study is to explore the existence Vocational Colleges developed by the Ministry of Education (MOE) and to identify elements of VC sustainable development.

\section{SUSTAINABLE DEVELOPMENT}

Brundtland (1987:37) stated that sustainable development has been conceptualized in a variety of purposes and one of them is "... development that meets the needs of the present without compromising the ability of future generations to meet their own needs... ". This concept of sustainability or sustainable development is defined for the first time in the Brundtland Commission Report, the World Commission on Environment and Development. It implies the development of the current generation without compromising the rights of future generations. Brundtland also claimed that the public should be concerned and take the memory of that development which will not affect the lives and welfare of the community in the coming days.

Mohamed Jallah (2004) claimed that the master-key to sustainable development is TVE. This is affirmed by Brundtland's statement in 1987. At the same time, the existence of VC is expected to produce more of the nation's workforce to further enhance economic growth. The country expects to produce more students who show interest to skills related TVE in order to further produce skilled human capital in the country.

\section{METHODOLOGY}

In particular, this study was conducted using the Delphi techniques. The aim is to obtain views and opinions of a high level of agreement among the panel of experts set up by the researcher. Delphi study was justified due its designed that is to optimize input obtained from an individual who are expert in their respective area.

Determination of criteria among the expert panels are basically guided from the following:

i. Posses a doctoral degree (Ph.D) in the field of TVE and vocational training,

ii. Teachers who have served more than 10 years in TVE and vocational training,

iii. Posses knowledge of the curriculum and VC implementation,

iv. Posses high position in the area of TVE and vocational training and expert in their respective area,

v. Senior Assistant from the MOE

Another criteria selected from the panels were their abilities and willingness to convey opinions and suggestions in respect of such matters (French, Psychol, Ho, \& Lee, 2002). Semi-structured interview were designed for data collection.

\section{DATA ANALYSIS}

A total of eight respondents involved actively in the Delphi study conducted. They were involved with interviews conducted in their respective institutions. The interviews were to get views and identify elements of continuity about VC in Malaysia. The selection process of respondents were in accordance with the 
selection criteria of the expert panel Delphi study which have been set at the early planning of the study. Details of respondents in the study is illustrated in Table 1.

Table 1: Panel of experts Delphi study based on the title and gender

\begin{tabular}{|l|c|c|c|}
\hline DESIGNATION & \multicolumn{2}{|l|}{ MALE } & FEMALE \\
\hline $\begin{array}{l}\text { Academic Staff from Public } \\
\text { Universities }\end{array}$ & 3 & - & 3 \\
\hline Training Institute Director & 1 & - & 1 \\
\hline $\begin{array}{l}\text { Lecturer Institute of Teacher } \\
\text { Education }\end{array}$ & 1 & - & 1 \\
\hline Ministry of Education Officer & 1 & - & 1 \\
\hline College Vocational Director & 1 & - & 1 \\
\hline Excellent Teacher & - & 1 & 8 \\
\hline \multicolumn{1}{|c|}{ TOTAL } & 7 & 1 & 1 \\
\hline
\end{tabular}

\section{IMPLEMENTATION AND CHALLENGES}

Nine issues or elements of sustainable development in the VC curriculum were identified from interviews among the panel of experts Delphi studies. These elements are the skills, counselor, committed management, internship among industries, collaboration and partnership, teaching techniques, entrepreneurship, soft skills, and curriculum.

\section{i. Skills}

Skills is an important element to VC students in order to study or work in the field they are trained. These skills will determine student's' pathway as soon as they graduated. Mohamad Salleh (2009) claimed that, to be a developing nation of excellence, glory and distinction, it must be supported by human capital of excellence, glory and distinction as well. Having a knowledgeable human capital and high-skilled worker are the most important factor for Malaysia to transform its economy towards achieving developed nation status with high income by 2020 (Ismail, 2012). He agreed with Norhafizah (2014) which stated that one of the efforts to achieve Vision 2020 envisaged is via education.

The expert panel believes that skills are essential elements for the sustainability of VC. It is more sustainable to meet the development needs of the country's human capital. Skills for a particular programme in technical education and should be given a priority. The statements below are collected from the interviews:

"VC provides skilled and semi-skilled workers to the development of the State, and to the economy."

"What we need here is something to refine the specific skills which derived from a broad area among learners. This is to support the development of vocational schools, in order to produce competence students in their own area."

"VC is designed for the purpose of developing this vocational field as a platform which can contribute to sustainable development of the country. Skilled workers are needed to the development of the country. These are the people who will work for the country."

"Moving towards the development of $21^{\text {st }}$ century, skilled and competent worker is required. At present, technical and vocational skill is growing rapidly in our country..."

\section{ii. Counselors}

Counselors are taken into consideration as another element in the preservation of VC. Majority students decided to enroll in VC with guidance and counselled by the teacher prior to their enrollment. 
Apart from the expert panel believes that the counselor has a good knowledge of related implementation in VC, counselors should provide ongoing support to students. Previously, according to a study conducted by Abd Hair Awang (2011), there are three parties which affect students' perceptions of technical and vocational education. They are (1) the parents, (2) counselors, and (3) teachers in the school. These parties provide a negative perception that TVE as a low level of qualifications, suitable for school drop outs and for students who are unable to meet the challenges of the school curriculum. In contrast, below are statement gathered from the interviews:

"Counselor plays a big role towards the development of VC, even from the initial stage of its implementation. One of the roles is to convice the stakeholders about the development of VC and career path for the children."

"Counselor should provide details input of the career path during the implementation of VC."

"The role of counselor should go hand-in-hand with other elements such as the levels of expertise and sufficient knowledge to provide information and knowledge about the advantages of VC in the system of Malaysia education."

Ramlee (2012), a teacher who was influenced by progressive ideas sees themselves as counselors to the students and facilitators of learning rather than the speaker to the subject being taught. Attitude to work more than the attitude adopted in class racing or competing with each other. Development of individuals according to their respective abilities takes more attention than development than others. It is backed by Mok (2009) which states that teachers have also always been a counselor/motivator to students by giving encouragement, strength, energy to lead, maintain the ideals and chain operations to achieve a goal.

\section{iii. Committed management}

In the field of TVE, the development of technology is a must to be followed in order to be associated with the content of current technology or technology skills. This includes motivation to increase knowledge and teaching skills by VC lecturers when attending staff development organized at their agencies or at the ministry level. The main idea is to help them during the process of teaching and learning in the workshop during classroom instruction.

In order to increase the quality of VC, committed management is one of the critical factors described in the literature reviewed by many researchers (Deming, 1986; Jennifer, 2004; Ismail, 2012). A committed management of VC will always find new measures to improve the performance of their services. As suggested by the respondent in the study, the committed management should improve the service performance so that it could be assessed based on the activities and actions performed. This is in line with Black and Porter (1996) that the management should show strong support for activities related to customer services, and Saraph, Benson, and Schroeder (1989) stated that activities and assessment should constantly be reviewed in order to get the latest input on the performance of their services. Below are statement gathered from the interviews:

"In training institution there are three important things namely governance model, training model and another one is a business model. All these three elements must be presented directly in the system..."

"Besides, the other element is to increase the number of programs offered in VC in line with industry demands at present."

The committed management in turn can drive the initiative to find measures that need to be done to achieve the level of service performance management commitment to VC.

\section{iv. Internship among industries}

Internship among industries is also an element suggested by respondents of the study. Internship provides exposure to students, and those experience provided during internship would ease students for their on-jobtraining and finding jobs after graduations. This will also guide and expose students with visits programmes and equipment in industries. The involvement of the industry to improve vocational education was started in 
early 2002 in England (Jenny Asher 2005). TVE programme or VC will be more successful and promote a very useful experience for students, especially from the cooperation of industries.

Internship is a field training program that aims to link the knowledge, skills and experience of existing real practice (BPG, KPM 2010). It provides students opportunity to improve their self-confidence and self-esteem. In VC context, the success of VC programmes is highly dependant on cooperation and collaboration by a party through public-private partnerships. This concept is adopted by those developed countries such as Germany and Finland, which both make TVE as an important educational resource. Josh Hawly (2012) claimed that collaboration between public sectors (government) and private sector (employers) are very important in the development of TVE. This is supported by Grubb and Lazerson (2004) statement about the consistentcy involvement among the public and private sectors which is crucial to the success of TVE developed country. These statements were supported from data gathered in the study:

"..collaboration with industry is a must"

"Collaboration with industries is important... However, it is quite difficult to find collaboration among industries due to students who are still under ages (below 18). Even students have already learned detailed in their area during classroom instruction, it is still in doubt whether they could perform themselves in the work space at that early age."

"Relationship among industries and VC management: For instance, this year, most Directors of VC initiate their interest to go into many industries to explain about VC development and to convince industries to provide opportunities for VC students' internship.."

\section{v. Collaboration and partnership}

Collaboration and partnership with the Public Training Institute (PTI) should be done to expose students to the equipment and machinery that is not in the VC workshop. Partnership between schools and technical education institutions such as Community College nearby is also necessary because of its benefits to students and lecturers involved with VC. According Batorski and Hughes (2002), sharing often increases the added value of a service or product. It will be beneficial to students, faculty, college and the management of this VC.

Organizing collaboration with other public or private institutions could enhance students' knowledge and experience from the usability of equipment and resources, and adapting and understanding in-depth the programmes of their respective area. Below are date gathere from the interviews related to collaboration and partnership in VC:

"Collaboration with other institutions such as public or private institutions, equipment, programmes, faculty, resources, and allocation from the government. All these are important to be instilled in VC"

"Networking with public and private institutions such as Industrial Trainings Institute and Giat MARA are developed to help VC students particularly in terms of equipment and study loans,"

\section{vi. Teaching techniques}

Various teaching techniques are provided in the curriculum specification for teachers to achieve their teaching objectives. Teaching method is crucial in TVE due to its importance to arouse students' interest into learning. In the teaching of $\mathrm{VC}$, it is recommended if teachers posses good teaching and master a variety of teaching techniques in the classroom instruction.

Shahril @ Charil (2005) states that the role of teachers in developing countries is very important. Effective teaching techniques suggested teachers to diversify teaching methods, provide teaching aids and deepen the content to be taught. In addition, teachers need to be aware of students' levels of education, motivate them to study hard, able to control their behaviors, and to provide regular assessments or examinations to students. Elements of teaching techniques considered to be important in the implementation of VC.

Mohd Zanal (2009) also demanded for teachers to have teaching techniques in teaching and learning, by focusing on hands-on experience, a visit to the factory, field work, laboratory work and placement in industries. Hee also suggested that teaching techniques should apply problem-solving skills, creativity and 
innovation skills in achieving sustainable development in the TVE. Below are statement gathered from the study:

'Element of stability in terms of the environment, society, must be applied in teaching"

"totally agree. Establish more students excel in terms of teaching and learning, profesionalisme, and industry relationships."

\section{vii. Entrepreneurship}

Entrepreneurship is one of the elements that has a significant influence on sustainable development of VC. Overall findings for this element found VC students should be given the opportunity to market the resulting product, VC curriculum should encourage students to become entrepreneurs, and VC lecturers should be given enough exposure in entrepreneurship. Many researchers noted that at least students know how to design a product or market a certain product. In addition they can also produce a cost-effective product and also has the characteristics of entrepreneurship others.

Tam, Suhaida and Abdul Patah (2008) have suggested that entrepreneurship in TVE can strengthen business skills through the activities undertaken. Accordingly, VC curriculum should encourage students to become entrepreneurs and students are given the opportunity to market the product. The teaching method is a form of experience between the methods appropriate for education and training for entrepreneurship (Shuman \& Hornaday 1975). Implementation of entrepreneurship education in VC is expected to help students to be more independent and earn their living either salaried or self-employed. Patterns such as mergers or the application of the characteristics of entrepreneurship in this area actually has been the practice in some developed countries such as Japan and Germany. Below are statement gathered from the interviews conveying ideas of respondents about entrepreneurship in VC:

"We have to refine exactly programmes developed in public areas, buildings, components, furniture.. it is related between one another, associated with entrepreneurship"

"The experience and learning gained by students allow students to become more confident to move on... and run their own business or company to meet the needs of themselves, society and the nation."

"We also encourage them to work alone. Vocational studenst are able to work alone. This is one of the advantages of vocational education. Students learn how to cope with environment in the real life situation. These are one of the important elements incorporated in VC curriculum"

Zaidatol Akmaliah and Habibah (2000) suggested the provision of instilled values and interest in VC in order to promote students' entrepreneurship or small business owner. These students can be born entrepreneurs via education and learning. This is pertaining to variety of subjects related to entrepreneurship were introduced in the year 2000 in the syllabus. They are Entrepreneurship education, business management, and business studies.

\section{viii. Soft skills}

Soft skills contributed to the preservation VC development. Soft skills need to be applied in VC particularly for students who will enter to the workforce which required by employers today. Jennifer (2004) stated that the communication skills and entrepreneurial skills allow students to communicate well between friend and teacher.

There are many researchers who have conducted studies related soft skills, especially at the level of higher learning institutions both public and private. This is the starting point of research conducted by some researchers to employers and industries. Consequently, the Ministry of Higher Education Malaysia has already introduced a number of specific skills which is known as soft skills in public university aims to ensure that every researcher will have the soft skills immediately after completing their studies at universities and meet the demands of employers and industry while working in the future. This refers to the study of William (2005), which found employers prefer workers who have the soft skills. 
In line with the development of VC and relates it with soft skills, below are suggested provided by respondents in the study:

"Students are still bound by their deeds. They must accept and understand the educational philosophy of the act and the country. Values still need to be implemented, early exposure to industry in the country and abroad."

"We do not produce VC students who are able to work but fail to communicate among their colleagues. They must have softskills too, in order to adapt with work environment.."

\section{ix. Curriculum}

Establishment of a good curriculum and on-going monitoring are essential in order to produce quality VC students and curriculum of the industry's needs. As written in newspaper articles online messenger (Published: 10/09/2011), Deputy Prime Minister of Malaysia, Tan Sri Muhyiddin Yassin said that the curriculum should be modular, competency-based and emphasizing the practical aspects. He further explained, curriculum will be known as the Standard Curriculum Vocational College (SCVC) which includes elements of creativity and innovation, entrepreneurship, skills and knowledge, combined technology intertwine with the needs of industry and professional bodies. This suggests that curriculum is one of the elements related to each other with the other elements that researchers have obtained in this study.

The goal of VC introduced is to produce skilled student in the relevant field of entrepreneurship and by all means, to enable them to get a job to start a business or to continue training at a high level (CDC 2001). Clearly specified, entrepreneurship has been emphasized into the curriculum to produce students who have basic or knowledge related to entrepreneurship. Thus, entrepreneurship plays an important role in shaping students to become entrepreneurs (Jonsson \& Jonsson 2003). Nevertheless, VC curriculum should be monitored from time to time so that the ultimate goal can be achieved and produced highly skilled VC graduates. Below are statement provided by respondents of the study, who has mutual agreement about curriculum of VC:

"The curriculum must be sustainable in order to produce people who are not harming the environment, the concern about safety, holistically..."

"The curriculum must be strongly established. The use of National Occupational Skills Standard (NOSS) by the curriculum is flexible to the needs of industry.."

\section{CONCLUSION}

In summary, this study has produced the elements of sustainable development for VC. Sustainability of VC will make it survive and establish in order to uphold the technical and vocational education. This is in line with the country towards becoming a high-income country as stipulated in the $11 \mathrm{MP}$. The quality of technical and vocational education is expected to be constantly updated and continuously contribute to the body of knowledge in TVE.

\section{REFERENCE LIST}

Abd Hair Awang (2011). Image and student loyalty towards Technical and Vocational Education and Training: Universiti Kebangsaan Malaysia.

Bahagian Pendidikan Guru (2010). Buku Panduan Internships. Kuala Lumpur. Kementerian Pelajaran Malaysia.

Batorski, M. \& Hughes, W. (2002). Beyond Process-centering: Emerging capability and alliance based business models. New York: Accenture.

Black, S. A. and Porter, L. J. (1996). Identification of the critical factors of TQM. Decision Sciences, 27 (1), 1 21. 
Brundtland Report (1987). In World Commission on Environment and Development. Our Common Future OUP.

Curriculum Development Centre (2002). Ministry of Education, Malaysia.

Deming, W. E. (1986). Out of crisis. Cambridge, MA: Massachusetts Institute of Technology Press.

French, P., Psychol, C., Yin-yo Ho \& Lee, L.S. (2002). A Delphi Survey of Evidence- Based Nursing Priorities in Hong Kong. Journal of Nursing Management (10): 265 - 273

Ismail, M. H., (2012). Kajian Mengenai Kebolehpasaran Siswazah di Malaysia: Tinjauan dari Perspektif Majikan. Prosiding Persidangan Kebangsaan Ekonomi Malaysia Ke VII. Ipoh, Perak: Universiti Kebangsaan Malaysia. ms. 906-913.

Ivan Hanafi (2007). Implementation of Technical and Vocational Education and Training at GermanMalaysia Institute, Malaysia. Doctorate Thesis. Universiti Putra Malaysia.

Jennifer, G. (2004). Generic Skills in vocational education and training: Dalam Jennifer, G. Research readings, halaman 7-18. Australia National Training Authority (ANTA): National Centre for Vocational Education Research (NCVER) Australia.

Johnson, B., \& Johnson, L. (2003). Education Research: Quantitative, Qualitative and Mixed Approach (2 ${ }^{\text {nd }}$ ed). Bostan, MA: Pearson Education, Inc.

Josh Hawley (2002). Public private partnerships in vocational education and training: International examples and models.

http://siteresources.worldbank.org/EXTECAREEGTOPEDUCATION/Resourses/44460711926365518 20/public_Private_Partnerships_in_Vocational_Education_and_Training.pdf. [18Julai 2014]

Mohamad, B. \& Salleh., M. J. (2009). Pembangunan Modal Insan Sebagai Satu Pelaburan Penting Dalam Konteks Pembinaan Negara. Prosiding "Seminar Pembangunan Modal Insan 2009", Tema: Kecemerlangan Modal Insan. Pusat Sumber Pendidikan Negeri, Pengkalan Chepa Kota Bharu Kelantan: Universiti Islam Antarabangsa Malaysia. ms. 1-17.

Mohammad Sani Ibrahim (2001). Perkembangan professionalisme guru: satu tuntutan dan satu kemestian. Seminar Nasional Perguruan dan Kepimpinan Pendidikan ke-10. Institut Aminuddin Baki, Genting Highlands.

Mohamed Jallah (2004). UNESCO-UNEVOC- An international experts meeting "learning for work", citizenshio and sustainability". The expert meeting on Bonn, Germany, 25-28 Oktober 2004.

Mohd Fuad Razali. (2010). Teras Strategik RMK-10 Membangun Modal Insan Bertaraf Dunia. Pendidik (75): 52 - 55

Mohd Zanal Dirin. (2009) Sustainable Development And Tvet.6 ${ }^{\text {th }}$ Annual National Technical And Vocational Education And Training Conference 2009. Concorde Hotel. Kuala Lumpur, 12-13 Mei 2009.

Mok, S. S. (2009). Pedagogi untuk Pengajaran dan Pembelajaran. 3rd ed. Kuala Lumpur: Multimedia Sdn. Bhd.

Nor Aini Idris (2002). Pendidikan dan pembasmian kemiskinan. Kajian kes mobiliti sosial di kalangan generasi kedua FELDA. DIm Prosiding SKIM 8: Pembangunan Manusia di Indonesia dan Malaysia. 810 Oktober, 2002, UKM.

Norhafizah Jalil (2014). Kecenderungan Pelajar Cemerlang Akademik Terhadap Pemilihan Bidang Ptv. Tesis ljazah Sarjana. Universiti Tun Hussein Onn Malaysia.

Rahmah Ismail (2003). Ekonomi pembangunan: Isu-isu sumber manusia. Bangi: Penerbit Universiti Kebangsaan Malaysia.

Ramlee Mustapha (2012). Prinsip Kepada Pendidikan Teknikal Dan Vokasional. Universiti Pendidikan Sultan Idris.

Saraph, J. V., Benson. P. G. and Schroeder, R. G. (1989). An instrument for measuring the critical factors of quality management. Decision Sciences, 20 (4), 810-828.

Shahril @ Charil Marzuki. (2005). Management of School Finance. PTS Publications, Kuala Lumpur

Shuman, J.C., \& Hornaday. J.A. ( 1975). Experiental learning in an entrepreneurial course, Collegiate News and Views 29 (1): 5-9. 
Tam Phun Khow, Suhaida Abdul Kadir \& Abdul Patah Malik. (2008). Pendidikan Keusahawanan Dalam Matapelajaran Vokasional. Dalam Pendidikan Teknik dan Vokasional: Suatu Perspektif Umum. Serdang: Penerbit Universiti Putra Malaysia.

UNESCO. (2004). Suggestions to UNESCO for Action Planning in TVET for Sustainable Development. Expert Meeting on Learning for Work, Citizenship and Sustainability, Bonn, October 2004. UNESCO, Paris http://www.unevoc.unesco.org/publications/pdf/SD_ActionPlan_e.pdf [6 Ogos 2014].

William, C. (2005). The Discursive Construction Of The 'Competent'learner Worker: From Key Competencies Of Employability Skills. Journals Studies In Continuing Education Faculty Of Education, University Of Technology Sydney, Australia 279(1):33-49.

Zaidatol Akmaliah Lope Pihie \& Habibah Elias. (2000). Pengajaran dan Pembelajaran Perdagangan, Keusahawanan dan Perdagangan Asas. Serdang: Penerbit Universiti Putra Malaysia. 